\title{
Response Surface Optimization of Electrocoagulation to Treat Real Indigo Dye Wastewater
}

\author{
Songphon Prayochmee ${ }^{1,2}$, Panomchai Weerayutsil ${ }^{2}$, Kulyakorn Khuanmar ${ }^{2 *}$ \\ ${ }^{1}$ Department of Environmental Science, Faculty of Science and Technology, Sakon Nakhon Rajabhat University, \\ Sakon Nakhon, 47000, Thailand \\ ${ }^{2}$ Department of Environmental Engineering, Faculty of Engineering, Khon Kaen University, Khon Kaen 40002, Thailand
}

Received: 16 July 2020

Accepted: 8 September 2020

\begin{abstract}
This research aimed to optimization of the electrocoagulation process was investigated in terms of chemical and physical mechanisms using Box-Behnken response surface design (BBD). The experimental conditions were optimized by examining the interaction effects of initial $\mathrm{pH}$, electrolysis time, and current density on COD and color removal efficiencies. The results showed that the calculated response functions agreed well with the experimental data, where $\mathrm{R}^{2}=94.87 \%$ for COD and $97.86 \%$ for color. An ANOVA analysis revealed p-values lower than 0.05 at the $95 \%$ confidence interval (CI) $(\mathrm{p}=0.05)$, confirming that the quadratic models were statistically significant and supportive of the phenomenon study on COD and color removal. According to BBD results, for the maximum removal of $\mathrm{COD}$ and color, the optimal independent variables were a $\mathrm{pH}$ of 4.0, electrolysis time of $60 \mathrm{~min}$, and current density of $300 \mathrm{~A} / \mathrm{m}^{2}$. Predicted removal efficiencies of COD and color under optimal operating conditions were $71.96 \%$ and $96.38 \%$, respectively. Three experiments conducted to confirm optimal operating conditions revealed mean values of COD and color removal efficiency to be $73.13 \%$ and $94.68 \%$, respectively. These findings confirmed that predictions of optimal operating conditions generated by the response surface design model were reliable.
\end{abstract}

Keywords: electrocoagulation, real indigo, Box-Behnken design, COD, color

\section{Introduction}

In the past, textile materials were colored by natural dyes made from plants, animals, and minerals. Many popular colorants were from plants such as indigo, a dyeing source used throughout the world. This was true

*e-mail: kulyakorn@kku.ac.th until the mid-19 $9^{\text {th }}$ century, when synthetic dyes were developed and then widely used in textile industries [1]. Currently, however, health and environmental issues caused by the textile industry's use of synthetic dyes are of significant concern and must be taken into consideration, specifically, the high volume of water consumed in the dyeing process and the untreated wastewater that contaminates natural water resources. Wastewater from textile industries consists of both 
organic and inorganic compounds, some of which are non-biodegradable and harmful to human health and the environment [2-3]. Therefore, natural dyes made from biodegradable and non-toxic substances are becoming trendy among people who like natural products. Of these, indigo dye is one of the most popular and is used to color products such as sarong, $t$-shirts, scarves, and bags.

Indigo dyeing is often carried out in small-scale industrial settings or community enterprise groups. The dyeing process generates irregular volumes of dark bluegreen wastewater containing high organic substances [4-5]. While the wastewater from the indigo dyeing process is biodegradable, it is characterized by insufficient nutrients for biological wastewater treatment, leading to the possibility of untreated wastewater being discharged directly into the environment. Moreover, the amount of wastewater created varies based on an irregular market demand and the producer's inconsistent free time, as indigo dyeing often contributes toward supplemental income among agriculturists

Due to the aforementioned characteristics of indigo dye wastewater, including its color, organic composition, and irregularity of production, Electrocoagulation (EC) is potentially a suitable treatment method, as this technique removes organic compounds and colloidal particles without requiring additional chemicals or microorganisms [6]. In comparison with other techniques, the EC process is compatible with a high variability of the water quality. In the EC process, electric current is applied to electrodes, triggering coagulant productions dissolved from the anode, while the cathode releases hydrogen gas and hydroxyl ions [7-8].

Factors that influence EC efficiency include electrolysis time, current density, electrode type, interelectrode spacing, and the $\mathrm{pH}$ of the electrolyte [9]. Response surface optimization is a widely used method to investigate optimal process variables of EC when aiming to obtain maximum treatment efficiency [10]. To predict the maximum response, a mathematical model is generated from response surface methodology using a statistically-based experimental design [11]. In this study, electrocoagulation was conducted to investigate optimal conditions for treating real indigo dye wastewater collected from a community enterprise group in Sakon Nakhon Province, Thailand. BoxBehnken response surface design (BBD) was used to optimize initial $\mathrm{pH}$, electrolysis time, and current density as process variables for COD and color removal.

\section{Material and Methods}

\section{Wastewater Samples and Chemicals}

Real indigo dye wastewater samples were collected from an indigo fabric community enterprise group in
Sakon Nakhon Province, Thailand. The wastewater was generated from the washing process, which produced approximately 100-200 L of indigo dye wastewater discharge per day. The wastewater samples were well-preserved according to standard methods at $4^{\circ} \mathrm{C}$ in a 20 -liter plastic container. Table 1 presents the characteristics of the wastewater samples, and the wastewater's dark blue-green color is shown in Fig. 1. The $\mathrm{pH}$ was adjusted to a desired value using an $\mathrm{H}_{2} \mathrm{SO}_{4}$ or $\mathrm{NaOH}$ solution (Merck, Germany). All reagents used in the experiments were analytical grade and used without additional purification.

\section{Electrocoagulation Process}

The experiment setup for electrocoagulation (EC) is shown in Fig. 2. The EC experiments were conducted at lab scale using a total volume of $500 \mathrm{ml}$ for each batch experiment. The EC cells were equipped with monopolar electrodes: one anode and one cathode, each with dimensions of $50 \mathrm{~mm} \times 150 \mathrm{~mm} \times 0.5 \mathrm{~mm}$ and made from aluminum 1100 sheets. The total effective electrode area was $50 \mathrm{~cm}^{2}$ and interelectrode spacing was $15 \mathrm{~mm}$. The electrodes were connected to a DC power supply (KPS3010D; 30V, 10A). The EC process was performed using 15 experimental runs with a 3-factor, 3-level Box-Behnken experimental design as described in Table 2. After finishing each experimental run, the wastewater was left to precipitate for 30 minutes. Then the supernatant water was filtered using sand filtration with $60-\mathrm{cm}$ depth. Finally, the clear water was analyzed for COD and color.

\section{Analytical Measurements}

Chemical oxygen demand (COD) measurements were determined according to standard methods for the examination of water and wastewater. The COD samples were analyzed using a $\mathrm{COD}$ reactor $(\mathrm{HACH}$ DRB200) and the color samples using an ADMI Spectrophotometer (HACH DR6000). The $\mathrm{pH}$ of the solutions was measured using a $\mathrm{pH}$ meter (METROHM 713). COD and color removal efficiency (R) calculations subsequent to electrocoagulation treatment were expressed as a percentage, given by

Table 1. Characteristics of the real indigo dye wastewater samples.

\begin{tabular}{|c|c|}
\hline Parameter & Value \\
\hline $\mathrm{pH}$ & $10.5-12.5$ \\
\hline COD $(\mathrm{mg} / \mathrm{L})$ & $2,500-3,100$ \\
\hline Color $(\mathrm{ADMI})$ & $800-930$ \\
\hline Suspended solids $(\mathrm{mg} / \mathrm{L})$ & $3,200-3,800$ \\
\hline Total dissolved solids $(\mathrm{mg} / \mathrm{L})$ & $3,100-5,200$ \\
\hline Conductivity $(\mu \mathrm{S} / \mathrm{cm})$ & $1,870-3,900$ \\
\hline
\end{tabular}




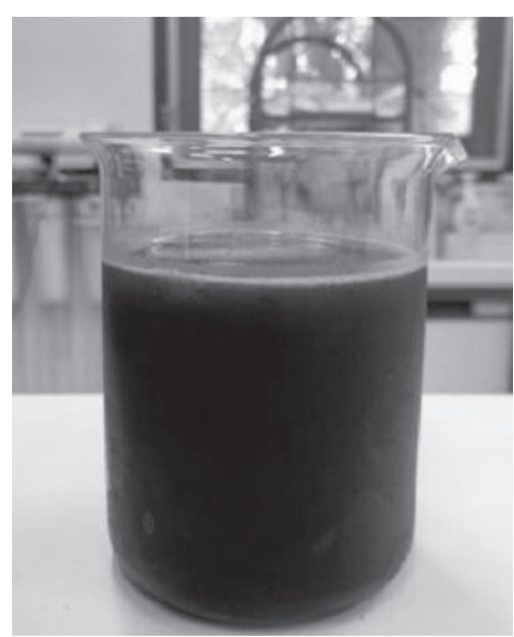

Fig. 1. Dark blue-green color of indigo dye wastewater.

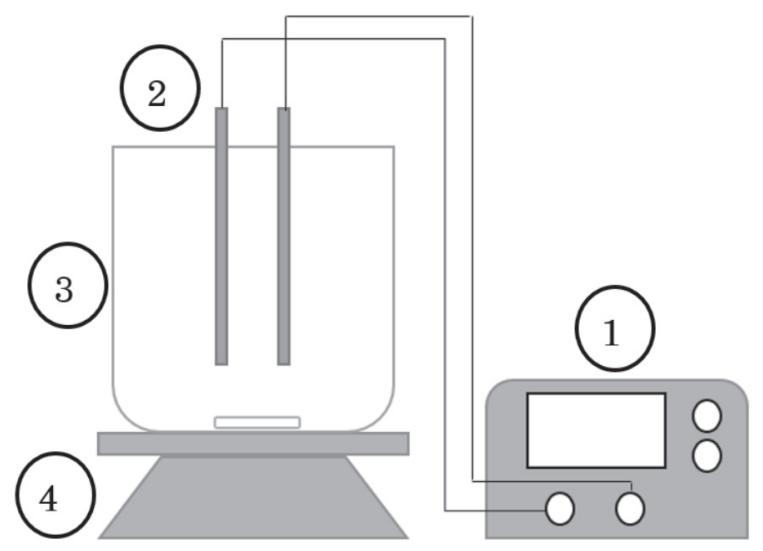

Fig. 2. Electrocoagulation reactor setup with monopolar electrodes. (1) DC power supply, (2) aluminum electrodes, (3) batch reactor, and (4) stirrer plate.

$$
\mathrm{R}(\%)=100\left(\mathrm{C}_{0}-\mathrm{C}_{1}\right) / \mathrm{C}_{0}
$$

...where $\mathrm{C}_{0}$ and $\mathrm{C}_{1}$ are initial and final coloration and COD, respectively [12-13].

\section{Experimental Design and Optimization}

As shown in Table 2, Box-Behnken response surface experimental design (BBD) with three factors and at three levels was used in optimizing and investigating

Table 2. Experimental design inputs and factors

\begin{tabular}{|c|c|c|c|c|}
\hline \multirow{2}{*}{ Independent variable } & \multirow{2}{*}{ Factor } & \multicolumn{3}{|c|}{ Coded level of variable } \\
\cline { 3 - 5 } & & -1 & 0 & 1 \\
\hline Initial $\mathrm{pH}$ & $\mathrm{X}_{1}$ & 4 & 7 & 10 \\
\hline Electrolysis time $(\mathrm{min})$ & $\mathrm{X}_{2}$ & 10 & 35 & 60 \\
\hline Current density $\left(\mathrm{A} / \mathrm{m}^{2}\right)$ & $\mathrm{X}_{3}$ & 100 & 200 & 300 \\
\hline
\end{tabular}

the influence of process variables, namely initial $\mathrm{pH}$ (4-10), electrolysis time (10-60 min), and current density $\left(100-300 \mathrm{~A} / \mathrm{m}^{2}\right)$, on COD and color removal [14].

The effects of the selected independent variables and their interactions on responses according to BBD were described using the second order polynomial equation

$\mathrm{Y}_{\mathrm{i}}=\beta_{0}+\Sigma_{\mathrm{i}=1}^{\mathrm{k}} \beta_{\mathrm{i}} \mathrm{X}_{\mathrm{i}}+\Sigma^{\mathrm{k}}{ }_{\mathrm{i}=1} \beta_{\mathrm{ii}} \mathrm{X}_{\mathrm{i}}^{2}+\sum_{\mathrm{j}=1}^{\mathrm{k}-1} \beta_{\mathrm{ij}} \mathrm{X}_{\mathrm{i}} \mathrm{X}_{\mathrm{j}}+\mathrm{C}$

...where $\beta_{0}, \beta_{\mathrm{i}}, \beta_{\mathrm{ii}}$, and $\beta_{\mathrm{ij}}$ are constant, linear, quadratic, and cross-factor interaction coefficients, respectively; $X_{i}$ and $X_{j}$ represent the independent variables; $Y_{i}$ is the predicted response; and $\mathrm{k}$ and $\mathrm{C}$ are the number of factors and the residual terms, respectively [15].

\section{Results and Discussion}

\section{Response Analysis and Interpretation Using Box-Behnken Design (BBD)}

Three factors in a three-level Box-Behnken response surface design (BBD) were used to optimize and examine the influence of process variables, namely $\mathrm{pH}$ $\left(\mathrm{X}_{1}\right)$, electrolysis time $\left(\mathrm{X}_{2}\right)$, and current density $\left(\mathrm{X}_{3}\right)$, on COD removal $\left(\mathrm{Y}_{1}\right)$ and color removal $\left(\mathrm{Y}_{2}\right)$ responses. Table 3 shows the independent variables' BBD matrix with uncoded and coded units as well as experimental and predicted response values. Values for the predicted responses in terms of COD and color removal efficiency were obtained from a quadratic regression model using the software mimitabl6 (trial version). The response functions with the determined coefficients for COD and color removal are given by Equations (3) and (4), respectively. The calculated response functions agreed well with the experimental data, which were $\mathrm{R}^{2}=94.87 \%$ for $\mathrm{Y}_{1}$ and $\mathrm{R}^{2}=97.86 \%$ for $\mathrm{Y}_{2}$.

$$
\begin{gathered}
\mathrm{Y}_{1}=51.3653+1.2017 \mathrm{X}_{1}+0.2433 \mathrm{X}_{2}+ \\
0.0519 \mathrm{X}_{3}-0.0375 \mathrm{X}_{1}^{2}-0.0020 \mathrm{X}_{2}^{2}- \\
0.0077 \mathrm{X}_{1} \mathrm{X}_{2}-0.0036 \mathrm{X}_{1} \mathrm{X}_{3}+0.0002 \mathrm{X}_{2} \mathrm{X}_{3} \\
\\
\mathrm{Y}_{2}=12.2081+1.3708 \mathrm{X}_{1}+1.1617 \mathrm{X}_{2}+ \\
0.31 \mathrm{X}_{3}+0.1181 \mathrm{X}_{1}^{2}-0.0086 \mathrm{X}_{2}^{2}-0.0003 \mathrm{X}_{3}^{2}- \\
0.0099 \mathrm{X}_{1} \mathrm{X}_{2}-0.0174 \mathrm{X}_{1} \mathrm{X}_{3}-0.0003 \mathrm{X}_{2} \mathrm{X}_{3}
\end{gathered}
$$

Analysis of variance (ANOVA) was used to examine the adequacy of the quadratic model and determine the quality of the correlation between parameters and responses. The evaluation was based on the p-values generated from the Minitab program, as shown in Table 4. The significance of the equations, individual parameters, and factor interaction were evaluated by analysis of variance (ANOVA) at the $95 \%$ confidence interval $(\mathrm{CI})(\mathrm{p}=0.05)$. P-values lower than 0.05 confirmed statistical significance of 
Table 3. Box Behnken experimental design matrix with experimental and predicted values.

\begin{tabular}{|c|c|c|c|c|c|c|c|}
\hline \multirow{3}{*}{ Run } & \multirow{3}{*}{$\begin{array}{c}\text { Initial } \mathrm{pH} \text {, } \\
\mathrm{X}_{1}\end{array}$} & \multirow{3}{*}{$\begin{array}{c}\text { Time (min), } \\
\mathrm{X}_{2}\end{array}$} & \multirow{3}{*}{$\begin{array}{l}\text { Current Density } \\
\qquad\left(\mathrm{A} / \mathrm{m}^{2}\right), \mathrm{X}_{3}\end{array}$} & \multicolumn{4}{|c|}{ Response (\%) } \\
\hline & & & & \multicolumn{2}{|c|}{ COD Removal, $Y_{1}$} & \multicolumn{2}{|c|}{ Color Removal, $\mathrm{Y}_{2}$} \\
\hline & & & & Experimental & Predicted & Experimental & Predicted \\
\hline 1 & 10 & 60 & 200 & 65.33 & 66.25 & 79.78 & 82.57 \\
\hline 2 & 7 & 10 & 300 & 64.19 & 64.31 & 65.09 & 66.47 \\
\hline 3 & 7 & 35 & 200 & 67.24 & 67.10 & 78.17 & 79.12 \\
\hline 4 & 10 & 35 & 300 & 66.29 & 65.91 & 77.36 & 75.53 \\
\hline 5 & 7 & 10 & 100 & 61.52 & 62.08 & 52.29 & 53.21 \\
\hline 6 & 7 & 35 & 200 & 66.86 & 67.10 & 79.38 & 79.12 \\
\hline 7 & 10 & 35 & 100 & 65.71 & 64.88 & 75.47 & 74.05 \\
\hline 8 & 7 & 35 & 200 & 67.24 & 67.10 & 79.78 & 79.12 \\
\hline 9 & 4 & 10 & 200 & 64.57 & 63.64 & 68.33 & 65.55 \\
\hline 10 & 4 & 60 & 200 & 69.52 & 69.24 & 89.35 & 88.88 \\
\hline 11 & 7 & 60 & 100 & 65.71 & 65.58 & 77.76 & 76.40 \\
\hline 12 & 4 & 35 & 300 & 69.14 & 69.90 & 89.35 & 90.79 \\
\hline 13 & 7 & 60 & 300 & 70.29 & 69.71 & 87.87 & 86.97 \\
\hline 14 & 10 & 10 & 200 & 62.67 & 62.95 & 61.73 & 62.21 \\
\hline 15 & 4 & 35 & 100 & 64.19 & 64.58 & 66.58 & 68.44 \\
\hline
\end{tabular}

the quadratic models and showed that they properly explained the phenomenon study on COD and color removal. Furthermore, the models' acceptability was examined using data plots of predicted versus actual values, presented in Fig. 3. The relationship between the predicted values calculated by the model and the experimental values determined by the obtained data is represented by a nearly diagonal line, indicating that both data generation methods were accurate and reliable. Therefore, the relationship was deemed suitable and an adequate model was achieved [16].

\section{Effects of Operating Parameters}

Figs 4-6 show two-dimensional (2D) contour plots representing the interaction effects of $\mathrm{pH}$, electrolysis time, and current density on removal efficiencies. The contour plots were generated from the mathematical models, presented in Equations (3) and (4), describing the process variable effects on COD and color removal efficiencies.

\section{Effects of Initial pH and Electrolysis Time}

The interaction effects of initial $\mathrm{pH}$ and electrolysis time on COD and color removal efficiencies, with current density being fixed at central level $\left(200 \mathrm{~A} / \mathrm{m}^{2}\right)$, are shown in Fig 4. The contour plot between initial $\mathrm{pH}$ and electrolysis time indicates a high efficiency for $\mathrm{COD}$ and color removal when the initial $\mathrm{pH}$ was lower than 7 , while initial $\mathrm{pH}$ values higher than 7 resulted in lower removal efficiencies. The main immediate reaction occurred from the aluminum used as electrodes in the EC process. The reactions can be described by Equations (5)-(7):

Anode:

$$
\begin{gathered}
\mathrm{Al} \rightarrow \mathrm{Al}^{3+}+3 \mathrm{e}^{-} \\
\mathrm{Al}^{3+}+3 \mathrm{OH}^{-} \rightarrow \mathrm{Al}(\mathrm{OH})_{3}
\end{gathered}
$$

Cathode:

$$
3 \mathrm{H}_{2} \mathrm{O}+3 \mathrm{e}^{-} \rightarrow(3 / 2) \mathrm{H}_{2}+3 \mathrm{OH}^{-}
$$

Table 4. Analysis of variance (ANOVA) for COD removal ( $\left.\mathrm{Y}_{1}\right)$ and color removal $\left(\mathrm{Y}_{2}\right)$.

\begin{tabular}{|c|c|c|}
\hline \multirow{2}{*}{ Source } & \multicolumn{2}{|c|}{$\mathrm{p}$-value } \\
\cline { 2 - 3 } & $\mathrm{Y}_{1}$ & $\mathrm{Y}_{2}$ \\
\hline Regression & 0.010 & 0.001 \\
\hline Linear & 0.002 & 0.000 \\
\hline Square & 0.182 & 0.031 \\
\hline Interaction & 0.161 & 0.047 \\
\hline $\mathrm{R}^{2}$ & $94.87 \%$ & $97.86 \%$ \\
\hline $\mathrm{R}^{2} \mathrm{adj}$ & $85.63 \%$ & $94.00 \%$ \\
\hline
\end{tabular}


a)

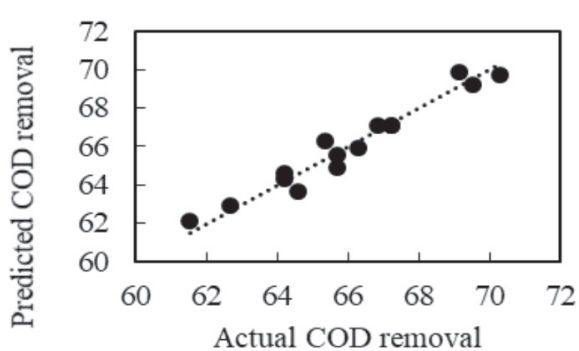

b)

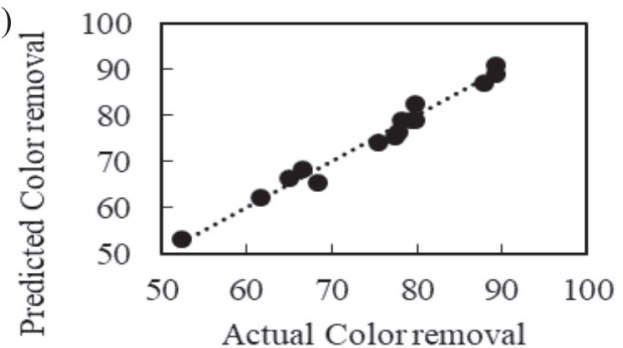

Fig. 3. Experimental versus predicted values plots for model adequacy testing of a) COD removal and b) color removal efficiencies using EC.

The major amorphous metallic $\mathrm{Al}$ was $\mathrm{Al}(\mathrm{OH})_{3}$ when $\mathrm{pH}$ was in the range of 5-7. The freshly formed amorphous $\mathrm{Al}(\mathrm{OH})_{3}$, having a large surface area, removed the colloidal particles in the wastewater by forming with the flocs of $\mathrm{Al}(\mathrm{OH})_{3(s)}$, causing the
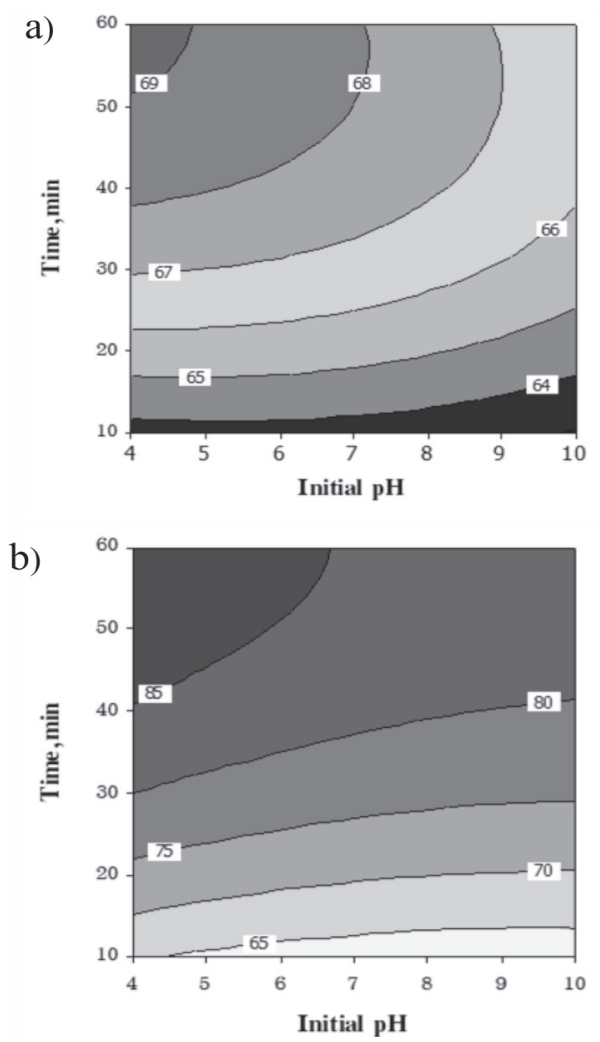

Fig. 4. Contour plots between $\mathrm{pH}$ and electrolysis time with responses on a) COD removal and b) color removal.
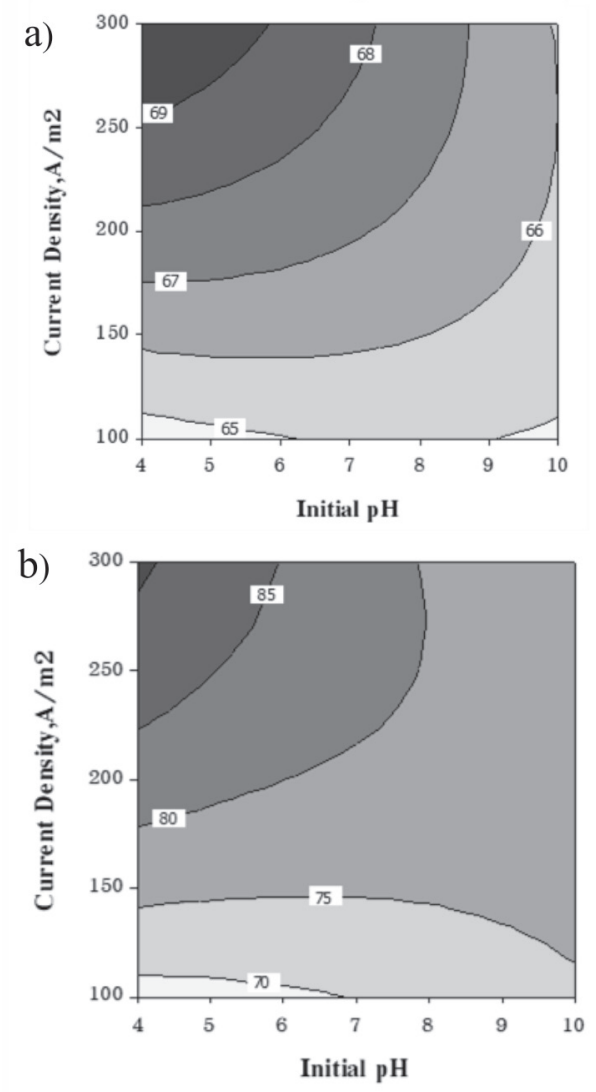

Fig. 5. Contour plots between $\mathrm{pH}$ and current density with responses on a) COD removal and b) color removal.

formed flocs to precipitate easily. Conversely, an initial $\mathrm{pH}$ higher than 7 resulted in low COD and color removal efficiency as a consequence of less formation of $\mathrm{Al}(\mathrm{OH})_{3}[17]$.

\section{Effects of Initial $\mathrm{pH}$ and Current Density}

The contour map in Fig. 5 shows the interaction between $\mathrm{pH}$ and current density as it affected COD and color removal efficiencies, with electrolysis time fixed at central level $(35 \mathrm{~min})$. The results revealed that increasing current density tended to increase COD and color removal efficiencies; however, COD and color removal had high efficiency only when the initial $\mathrm{pH}$ was lower than 7. This confirmed that when using EC, initial $\mathrm{pH}$ is an important parameter of COD and color removal efficiencies [18].

\section{Effects of Electrolysis Time and Current Density}

Fig. 6 shows the contour map based on the interaction between electrolysis time and current density and its effects on COD and color removal efficiencies, with $\mathrm{pH}$ fixed at central level ( $\mathrm{pH}$ 7). This study found that long electrolysis time and high current density resulted in increased COD and color removal efficiencies on condition that the initial $\mathrm{pH}$ was lower than 7 [19]. 

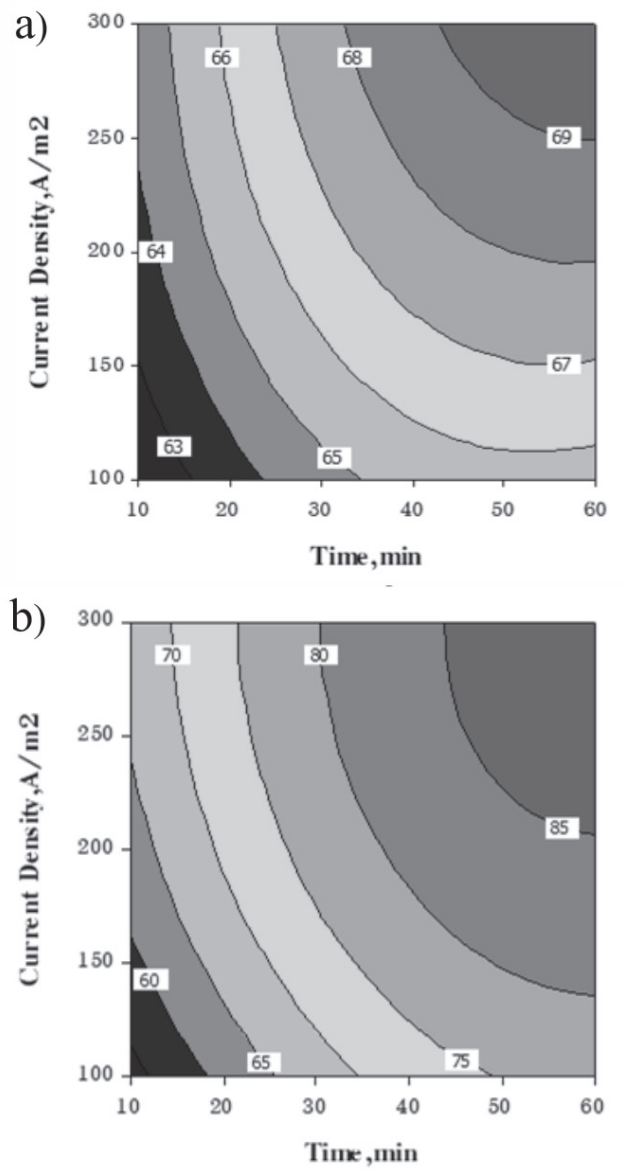

Fig. 6. Contour plots between electrolysis time and current density with responses on a) COD removal and b) color removal.

\section{Optimization Using Box-Behnken Design}

Multi-response numerical optimization technique was carried out to determine the optimal operating conditions for maximum COD and color removal efficiencies when using electrocoagulation to treat real indigo dye effluent. According to BBD results, depicted in Fig. 7, maximum removal of COD and color occurred under the following operating conditions: a $\mathrm{pH}$ of 4.0, an electrolysis time of $60 \mathrm{~min}$, and a current density of $300 \mathrm{~A} / \mathrm{m}^{2}$. Under these optimal conditions, the COD removal efficiency and color removal efficiency were reported to be $71.96 \%$ and $96.38 \%$, respectively. Three tests were conducted to validate the optimal conditions. Mean values of the test results were $73.13 \%$ for COD removal and $94.68 \%$ for color removal. The observed responses were found to be in close agreement with the predicted values obtained from the numerical optimization technique.

\section{Conclusions}

The experimental conditions were optimized by observing the effects of interactions among variables

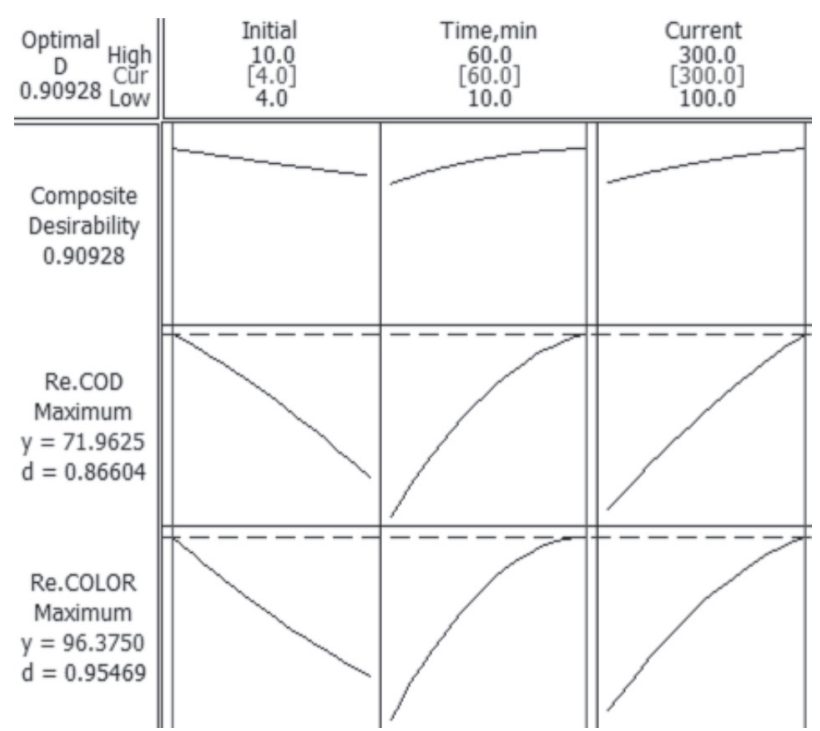

Fig. 7. Process optimization for COD and color removal.

(initial $\mathrm{pH}$, electrolysis time, and current density) on $\mathrm{COD}$ and color removal efficiencies using a response surface methodology (RSM) with Box-Behnken design. The calculated response functions agreed well with the experimental data, where $\mathrm{R}^{2}=94.87 \%$ for COD and $\mathrm{R}^{2}=97.86 \%$ for color. ANOVA results at the $95 \%$ confidence interval $(\mathrm{CI})(\mathrm{p}=0.05)$ revealed $p$-values lower than 0.05 , confirming that the quadratic models were statistically significant and properly explained the phenomenon study on COD and color removal. The contour plot of initial $\mathrm{pH}$, electrolysis time, and current density indicated that COD and color removal occurred at high efficiencies when the initial $\mathrm{pH}$ was lower than 7, while an initial $\mathrm{pH}$ higher than 7 resulted in lower removal efficiencies. It was also shown that long electrolysis time and high current density resulted in increasing COD and color removal efficiencies as long as the initial $\mathrm{pH}$ was lower than 7. According to the BBD results, optimal operating conditions to obtain the maximum removal of $\mathrm{COD}$ and color are: a $\mathrm{pH}$ of 4.0, electrolysis time of $60 \mathrm{~min}$, and current density of $300 \mathrm{~A} / \mathrm{m}^{2}$. Under these optimal conditions, the COD and color removal efficiencies were found to be $71.96 \%$ and $96.38 \%$, respectively.

\section{Acknowledgements}

This research was financially supported by the Farm Engineering and Automatic Control Technology Research Group, Faculty of Engineering, Khon Kaen University, Thailand.

\section{Conflict of Interest}

The authors declare no conflict of interest. 


\section{References}

1. ERKAN G., SENGUL K., KAYA S. Dyeing of white and indigo dyed cotton fabrics with Mimosa tenuiflora extract. Journal of Saudi Chemical Society. 18, 139, 2014.

2. HASSAAN M.A., NEMR A.E. Health and environmental impacts of dyes: mini review. American Journal of Environmental Science and Engineering. 1 (3), 64, 2017.

3. LELLIS B., FAVARO-POLONIO C.Z., PAMPHILE J.A., POLONIO J.C. Effects of textile dyes on health and the environment and bioremediation potential of living organisms. Biotechnology Research and Innovation. 3 (2), $275,2019$.

4. TELI M.D., AMBRE P. Development of compound shades of indigo and marigold using natural mordants on cotton and cotton/viscose blend. Journal of the Textile Association. 78 (1), 15, 2017.

5. CHANORN C. Dialectics of cultural production: Branding indigo-dyed textiles in Sakon Nakhon, Thailand. Textile Cloth and Culture. 17 (3), 312, 2019.

6. BAZRAFSHAN E., MOHAMMADI L., ANSARIMOGHADDAM A., MAHVI A.H. Heavy metals removal from aqueous environments by electrocoagulation process - a systematic review. Journal of Environmental Health Science \& Engineering. 13 (74), 1, 2015.

7. DARMADI D., LUBIS M.R., HIZIR R., CHAIRUNNISAK A., ARIFIN B. Comparison of palm oil mill effluent electrocoagulation by using Fe-Fe and Al-Al electrodes: box-behnken design. Asean Journal of Chemical Engineering. 18 (1), 30, 2018.

8. KERMET-SAID H., MOULAI-MOSTEFA N. Optimization of turbidity and cod removal from pharmaceutical wastewater by electrocoagulation: isotherm modeling and cost analysis. Polish Journal of Environmental Studies. 24 (3), 1049, 2015.

9. LUBIS M.R., FUJIANTI D.S., ZAHARA R., DARMADI D. The optimization of the electrocoagylation of palm oil mill effluent with a box-behnken design. International Journal of Technology. 10 (1), 137, 2019.

10. ARULMATHI P., ELANGOVAN G., BEGUM A.F. Optimization of electrochemical treatment process conditions for distillery effluent using response surface methodology. The Scientific World Journal. 2015, 1, 2015.

11. KARICHAPPAN T., VENKATACHALAM S., JEGANATHAN P.M. Optimization of electrocoagulation process to treat grey wastewater in batch mode using response surface methodology. Journal of Environmental Health Sciences \& Engineering. 12 (29), 1, 2014.

12. ZHU M., YIN X., LIU Q., FENG Z. Optimization and modelling using the response surface methodology for methylene blue removal by electrocoagulation / hazelnut shell adsorption coupling in a batch system. Polish Journal of Environmental Studies. 29 (3), 2493, 2020.

13. NOUREN S., SARWAR M., MUHI-UD-DIN G., YAMEEN M., BHATTI H.N., SOOMRO G.A., SULEMAN M., BIBI I., KAUSAR A., NAZIR A., IQBAL M. Sweet lime-mediated decolorization of textile industry effluents. Polish Journal of Environmental Studies. 28 (1), 283, 2019.

14. TAK B.Y., TAK B.S., KIM Y.J., PARK Y.J., YOON Y.H., MIN G.H. Optimization of color and cod removal from livestock wastewater by electrocoagulation process: application of box-behnken design (BBD). Journal of Industrial and Engineering Chemistry. 28, 307, 2015.

15. CHOLLOM M.N., RATHILAL S., SWALAHA F.M., BAKARE B.F., TETTEH E.K. Comparison of response surface methods for the optimization of an upflow anaerobic sludge blanket for the treatment of slaughterhouse wastewater. Environmental Engineering Research. 25 (1), 114, 2020.

16. HENDAOUI K., AYARI F., RAYANA I.B., AMAR R.B., DARRAGI F., TRABELSI-AYADI M. Real indigo dyeing effluent decontamination using continuous electrocoagulation cell: study and optimization using response surface methodology. Process Safety Environmental Protection. 116, 578, 2018.

17. SARASWATHY T., SINGH A., RAMESH S.T. New trends in electrocoagulation for the removal of dyes from wastewater: a review. Environmental Engineering Science. 30 (7), 333, 2013.

18. KARTIKANINGSIH D., SHIH Y.J., HUANG Y.H. Boron removal from boric acid wastewater by electrocoagulation using aluminum as sacrificial anode. Sustainble Environment Research. 26, 150, 2016.

19. HAKIZIMANA J.N., GOURICH B., CHAFI M., STIRIBA Y., VIAL C., DROGUI P., NAJA J. Electrocoagulation process in water treatment: a review of electrocoagulation modeling approaches. Desalination. 404, 1, 2017. 